\title{
Assessing the site of increased intestinal permeability in coeliac and inflammatory bowel disease
}

\author{
K Teahon, S Somasundaram, T Smith, I Menzies, I Bjarnason
}

\begin{abstract}
Background-The precise site of intestinal permeability changes in patients with coeliac and inflammatory bowel disease is unknown.

Aims-To design a non-invasive technique for the localisation of altered gastrointestinal permeability to ${ }^{51} \mathrm{chromium}$ labelled EDTA ( ${ }^{51}$ CrEDTA). The method depends on comparing and defining concentration/ time profiles in serum of a series of simultaneously ingested indicators with a well defined absorption site (3-0-methylD-glucose (jejunal indicator), ${ }^{57}$ cobalt labelled vitamin $B_{12}$ (ileal indicator), and sulphasalazine (caecal-colonic indicator)) in relation to simultaneously ingested ${ }^{51}$ CrEDTA.
\end{abstract}

Subjects-Five normal controls, six patients with untreated coeliac disease, five with Crohn's ileitis, and five with pan-ulcerative colitis underwent study, which entailed the simultaneous ingestion of the above four test substances followed, during the next 24 hours, by timed serial collection of urine and serum for marker analysis.

Results-Urinary excretion of ${ }^{51}$ CrEDTA was significantly increased in all patient groups. Analysis of serum appearances and profiles of the markers suggested that the increased intestinal permeation of ${ }^{51}$ CrEDTA took place in the diseased jejunum in patients with coeliac disease, predominantly in the ileum in Crohn's disease and in the colon in the patients with pan-ulcerative colitis.

Conclusion-A new non-invasive technique has been assessed that permits the localisation of the site of permeability changes with the gastrointestinal tract. (Gut 1996; 38: 864-869)

Pharmacology,

Wolfson Unit,

University of

Newcastle upon Tyne

$\mathrm{K}$ Teahon

Department of Clinical Biochemistry, King's College School of

Medicine and

Dentistry, London

$S$ Somasundaram

T Smith

I Menzies

I Bjarnason

Correspondence to: Dr K Teahon, Department of Gastroenterology, Nottingham City Hospital, Hucknell Road, Nottingham NG5 1PB.

Accepted for publication 7 December 1995 intestinal barrier function in the aetiology and pathogenesis of intestinal and systemic disease. ${ }^{12}$ Choice of test procedure for assessing intestinal permeability depends on clinical and experimental circumstances. In general there is good agreement between results obtained with the five hour differential urinary excretion of lactulose/L-rhamnose (or lactulose/mannitol) and the 24 hour urinary excretion of ${ }^{51}$ chromium labelled EDTA $\left({ }^{51} \mathrm{CrEDTA}\right) .^{2-4}$ After ingestion the uptake of test sugars, which are subjected to rapid bacterial degradation after reaching the caecum, being largely from the small intestine is not affected by colonic pathology. In the case of ${ }^{51} \mathrm{CrEDTA}$ given by itself, distinction between small intestine and colonic contributions to the 24 hour urinary excretion is uncertain.

In an attempt to discriminate between changes in small intestinal and colonic permeability Jenkins et $a l^{5}$ administered lactulose, L-rhamnose, and ${ }^{51} \mathrm{CrEDTA}$ together and measured timed excretions of these markers in urine. The ratio of urinary lactulose/L-rhamnose during the first five hours provided an index of small intestinal permeability, and the total 24 hour urinary excretion of ${ }^{51} \mathrm{CrEDTA}$, less that of lactulose (as \% of doses) served as an index of colonic permeability. ${ }^{5}$ The results showed that the colon was likely to be the site of increased intestinal permeation of ${ }^{51}$ CrEDTA in patients with active panulcerative colitis, ${ }^{5}$ and others have found similar changes after abdominal radiation. ${ }^{6}$ Nevertheless the technique does not permit the additional differentiation between an upper and lower small intestinal site of altered intestinal permeability that is possible using the technique we now report, based on serum concentration/time profiles after ingestion of ${ }^{51} \mathrm{CrEDTA}$ together with 3-0-methylD-glucose, ${ }^{57}$ Cobalt labelled vitamin $\mathbf{B}_{12}$ $\left({ }^{57} \mathrm{CoVit} \mathrm{B}_{12}\right)$, and sulphasalazine, which serve as indicators of absorption site.

\section{Methods}

Basis of test procedure

The principle of the test was to compare the serum concentration/time profiles of three absorption indicators, selected because each is specifically absorbed from a defined region within the intestinal tract, with that of simultaneously ingested ${ }^{51} \mathrm{CrEDTA}$, which should, in theory, permit assessment of the main intestinal site of ${ }^{51} \mathrm{CrEDTA}$ permeation. The indicators used were 3-0-methyl-D-glucose, absorbed from the jejunum by an active carrier mediated transport system shared with $D$ glucose and D-galactose, ${ }^{7}$ vitamin $B_{12}$, specifically absorbed as a complex with intrinsic factor by carriers in the ileum, ${ }^{8}$ and sulphasalazine, which is metabolised by the azoreductase of bacteria in the caecum and colon 
to yield 5-aminosalicylic acid and sulphapyridine. ${ }^{9}$ The first appearance of 3-0-methyl-Dglucose, ${ }^{57} \mathrm{CoVitB}_{12}$ and sulphapyridine in serum should therefore indicate the arrival of the 'head' of the test solution after oral administration in the jejunum, ileum, and caecum, respectively, provided that the rate of mucosal uptake is similar for each of the indicators. ${ }^{9}$ The subsequent serum concentrations/time profiles are determined by the same factors that influence the pharmacokinetic profile of an ingested drug, namely the site and relative efficiency of mucosal uptake, the rate of intestinal transit, metabolic degradation (for sulphapyridine), volume of systemic distribution and rate of clearance. Because of the nature of the test most of these factors apply equally to all the test substances. However, as renal function is an important determinator of the permeation profiles glomerular filtration rates were assessed during each test.

\section{Subjects}

Five healthy volunteers acted as controls (four males, one female, mean age 37 years, range 22-58). Six symptomatic, newly diagnosed patients with coeliac disease (four males, two females, mean age 42 years, range 32-56), five patients with Crohn's ileitis of activity index over $150^{10}$ (four males, one female, mean age 29 years, range 20-42), and five patients (all males, mean age 44 years, range 26-59) with active pan-ulcerative colitis as defined by Truelove et al $^{11}$ were studied.

All the patients with inflammatory bowel disease had sufficiently severe disease activity to warrant hospital admission. Three were receiving 5-aminosalicylic acid. The studies were carried out before treatment was changed and no patient was receiving corticosteroids or immunosuppressants. Disease location in patients with inflammatory bowel disease had been established but was confirmed by colonoscopy, radiology or ${ }^{111}$ indium leucocyte scintigrams, or all three, within a week of these studies.

The reliability of 'first appearance in serum' to indicate arrival at a particular level in the intestine requires that mucosal uptake of the markers used is not unduly delayed and takes place at a similar rate. The rates of mucosal permeation for ${ }^{57} \mathrm{CoVitB}_{12}$ and sulphapyridine have been assessed previously. ${ }^{8912}$ To assess the relative mucosal permeation rates of 3-0 methyl-D-glucose and ${ }^{51}$ CrEDTA in the same intestine four patients (males, mean age 38 years, range 32-40) with the irritable bowel syndrome, undergoing routine gastroduodenoscopy, had a test solution containing 3-0methyl-D-glucose $(2.5 \mathrm{~g})$ and ${ }^{51}$ CrEDTA (1 $\mathrm{mCi}$ ) in $50 \mathrm{ml}$ water instilled directly into the duodenum. Serum samples taken before, and at five minute intervals for a period of 30 minutes after instillation, were assayed for these markers.

No subject had recently had alcohol (within seven days), non-steroidal anti-inflammatory drugs or other drugs (within six months) known to affect intestinal integrity. ${ }^{2}$
These studies were approved by the Harrow and Camberwell Health Authority Ethical Committees and all subjects gave informed consent.

\section{Procedure}

All subjects were admitted to a metabolic research ward for the study. They fasted from 12 hours before the test until the study was complete. Throughout the studies they lay supine except for toilet purposes. At 7 am on the day of the test subjects received an intramuscular injection of cyanocobalamine $(1 \mathrm{mg}$ in $1 \mathrm{ml}$, Glaxo, UK) to saturate vitamin $B_{12}$ receptors and hence to facilitate the detection of ${ }^{57} \mathrm{CoVitB}_{12}$ in serum. An indwelling intravenous cannula was placed into the antecubital veins of both arms, one being used for intravenous injection and fluid replacement (started at $11 \mathrm{am} ; 3$ litres of glucose-saline with 60 meq potassium given over 18 hours) and the other for obtaining blood samples for analyses.

At 7.45 am subjects swallowed two capsules containing human intrinsic factor (Amersham International, Amersham, Buckinghamshire, UK and Frost Laboratories, Quebec, Canada) with $20 \mathrm{ml}$ of water. At exactly 8 am patients received $10 \mathrm{ml}$ of sterile saline intravenously containing $100 \mu \mathrm{Ci}^{99}$ technetium diethylenetriaminopenta acetate ( $\left.{ }^{99 \mathrm{~m}} \mathrm{TcDTPA}\right) \quad(3 \cdot 7$ $\mathrm{MBq}$, Amersham International) over a period of 10 seconds while drinking the $100 \mathrm{ml}$ test solution (within one minute), which contained: 3-0-methyl-D-Glucose $(2.5 \mathrm{~g}$, Sigma, Poole, Dorset, UK), ${ }^{57} \mathrm{CoVitB}_{12}(5 \mu \mathrm{Ci}, 19$ $\mathrm{kBq}$, Amersham International), sulphasalazine (2.0 g, Syrup, Pharmacia, Milton Keynes, UK), ${ }^{51} \mathrm{CrEDTA}(1 \mathrm{mCi}, 37 \mathrm{MBq}$, Amersham International).

Ten $\mathrm{ml}$ of blood was obtained before the test, at five minute intervals for the first 30 minutes, at one hour, hourly until $8 \mathrm{pm}$ and two hourly until completion of the test at 8 am the next morning. A complete 24 hour urinary collection was made.

The radiation dose received during the test is less than $1.5 \mathrm{mSieverts.}$

\section{Marker analyses}

To ensure precision the $99 \mathrm{~m}$ TcDTPA, ${ }^{57} \mathrm{CoVitB}_{12}$, and ${ }^{51} \mathrm{CrEDTA}$ doses for ingestion were all weighed. The blood samples were allowed to clot, spun down, and the serum collected. Exactly $1.0 \mathrm{ml}$ of each serum sample and $5 \mathrm{ml}$ of urine was counted along with standards on a LKB 1280 or 1282 gammacounter along with appropriate standards. The ${ }^{99 \mathrm{~m}} \mathrm{Tc}$ was counted on the day of the test. One week later, when all ${ }^{99 m} \mathrm{Tc}$ activity had decayed, the samples and standards were counted for ${ }^{57} \mathrm{Co}$ and ${ }^{51} \mathrm{Cr}$, appropriate crossover corrections being made.

To calculate glomerular filtration rates the ${ }^{99} \mathrm{~m} \mathrm{Tc}$ disappearance data in serum was plotted (\% dose/litre) on a logarithmic scale and the linear part of the slope extrapolated to the $y$ axis. The intercept value divided into $100 \%$ 
Time of first appearance of test markers in serum and glomerular filtration rates

\begin{tabular}{|c|c|c|c|c|c|c|c|c|c|c|c|c|c|c|c|c|c|c|c|c|c|}
\hline & \multicolumn{21}{|c|}{ Patient numbers } \\
\hline & \multicolumn{5}{|c|}{ Normal controls } & \multicolumn{6}{|c|}{ Coeliac disease } & \multicolumn{5}{|c|}{ Crohn's disease } & \multicolumn{5}{|c|}{ Ulcerative colitis } \\
\hline & 1 & 2 & 3 & 4 & 5 & 1 & 2 & 3 & 4 & 5 & 6 & 1 & 2 & 3 & 4 & 5 & 1 & 2 & 3 & 4 & 5 \\
\hline $\begin{array}{l}\text { 3-0-m-D-glucose } \\
\text { 51CrEDTA } \\
\text { 57CoVitB12 } \\
\text { Sulphapyridine } \\
\text { GFR (ml/min) }\end{array}$ & $\begin{array}{r}20 \\
30 \\
240 \\
180 \\
121\end{array}$ & $\begin{array}{r}10 \\
60 \\
300 \\
180 \\
135\end{array}$ & $\begin{array}{r}15 \\
60 \\
300 \\
240 \\
112\end{array}$ & $\begin{array}{r}10 \\
60 \\
180 \\
300 \\
113\end{array}$ & $\begin{array}{r}5 \\
25 \\
300 \\
300 \\
123\end{array}$ & $\begin{array}{r}10 \\
5 \\
120 \\
180 \\
131\end{array}$ & $\begin{array}{r}30 \\
30 \\
240 \\
240 \\
105\end{array}$ & $\begin{array}{r}10 \\
20 \\
360 \\
360 \\
108\end{array}$ & $\begin{array}{r}5 \\
5 \\
180 \\
300 \\
97\end{array}$ & $\begin{array}{r}60 \\
60 \\
300 \\
420 \\
110\end{array}$ & $\begin{array}{r}20 \\
10 \\
180 \\
240 \\
119\end{array}$ & $\begin{array}{r}5 \\
10 \\
300 \\
180 \\
127\end{array}$ & $\begin{array}{r}10 \\
15 \\
240 \\
240 \\
111\end{array}$ & $\begin{array}{r}10 \\
10 \\
120 \\
120 \\
101\end{array}$ & $\begin{array}{r}10 \\
60 \\
240 \\
240 \\
116\end{array}$ & $\begin{array}{r}10 \\
15 \\
300 \\
420 \\
134\end{array}$ & $\begin{array}{r}5 \\
60 \\
300 \\
360 \\
102\end{array}$ & $\begin{array}{r}15 \\
60 \\
240 \\
240 \\
118\end{array}$ & $\begin{array}{r}10 \\
10 \\
180 \\
240 \\
94\end{array}$ & $\begin{array}{r}10 \\
15 \\
240 \\
120 \\
115\end{array}$ & $\begin{array}{r}10 \\
20 \\
360 \\
300 \\
129\end{array}$ \\
\hline
\end{tabular}

and multiplied by $1000 \mathrm{ml}$ gives the extracellular volume distribution of ${ }^{99 \mathrm{~m}} \mathrm{TcDTPA}$ (in $\mathrm{ml}$ ). This is then multiplied by $\lambda$, which is the slope of the linear part of the ${ }^{99 \mathrm{~m}} \mathrm{TcDTPA}$ disappearance plot, and this gives the glomerular filtration rate $(\mathrm{ml} / \mathrm{min}) .{ }^{13}$

Serum 3-0-methyl-D-glucose was measured by thin layer chromatography and densitometry as previously described ${ }^{14}$ and sulphapyridine by high pressure liquid chromatography with ultraviolet detection ${ }^{15}$ both of which have satisfactory accuracy and precision, coefficients of variation ranges being $3 \cdot 5-8 \%$ and $4-11 \%$, respectively.

\section{Statistics}

Statistical significance between patient groups was assessed by Wilcoxon's rank sum test.

\section{Results}

The rest was well tolerated by all except one normal subject who had severe nausea and vomiting, starting six hours after start of the test and coinciding with the rise in the serum sulphapyridine value.

Appearance of markers in serum and renal function Detectable values of both 3-0-methyl-Dglucose and ${ }^{51} \mathrm{CrEDTA}$ appeared in serum at the same time after instillation into the duodenum, at five minutes in three patients with irritable bowel syndrome, and at 10 minutes in the fourth.

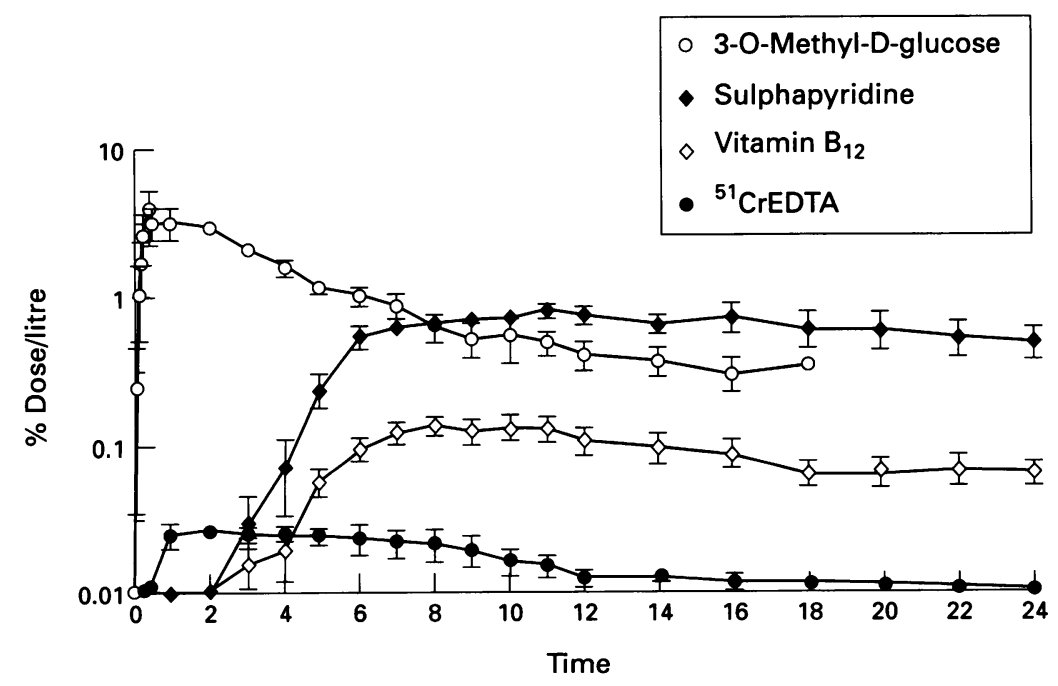

Figure 1: Permeation profiles from normal subjects. Vertical axis shows the \% dose/litre of the test substances in serum (on a logarithmic scale) over 24 hours after their simultaneous ingestion.
In the main study serum creatinine was normal in all subjects. The Table shows that glomerular filtration rates varies from 94 $\mathrm{ml} / \mathrm{min}$ to $138 \mathrm{ml} / \mathrm{min}$, which is within the reported normal physiological range for these age groups, and there were no significant difference between the study groups.

The Table shows the time of first appearance of 3-0-methyl-D-glucose, ${ }^{51}$ CrEDTA, ${ }^{57} \mathrm{CoVitB}_{12}$ and sulphapyridine in serum after oral administration. While there is some variation between different people in the time of first appearance of each marker, there was no significant $(p>0.3)$ difference between patient groups except for the appearance of ${ }^{51}$ CrEDTA. Appearances of 3-0-methyl-Dglucose precedes that of ${ }^{51} \mathrm{CrEDTA}$ in both the normal and ulcerative colitis groups $(p<0.05)$, but no significant difference was found in the time of appearance of these two markers in the serum of patients with coeliac and ileal Crohn's disease.

The appearance of ${ }^{57} \mathrm{CoVitB}_{12}$ preceded that of sulphapyridine in eight subjects, but in seven subjects these markers appeared at the same time, and in the remaining six the 'caecal' marker preceded the 'ileal' marker. The gastric to caecal transit time was usually in the range of three to six hours and did not differ significantly between the groups.

\section{Permeation profiles}

The summation permeation profiles (mean (SEM)) from the four different groups are shown in Figures 1-4.

Figure 1 shows the permeation profile for the normal group. Peak levels of ${ }^{51} \mathrm{CrEDTA}$ (less than $0.046 \%$ of the dose/litre in each case) are achieved one to two hours (in one case ${ }^{51}$ CrEDTA peaked at six hours) after the appearance of 3-0-methyl-D-glucose, but before the appearance of the 'ileal' and 'caecal' markers. Insignificant serum values of ${ }^{51}$ CrEDTA were found between eight and 14 hours after starting the test, and only one normal subject had detectable values throughout the 24 hour period. The mean 24 hour urinary excretion of ${ }^{51} \mathrm{CrEDTA}$ was $2 \cdot 13$ $(0.31) \%$, range 1.46 to $3.15 \%$.

Figure 2 shows the permeation profile from the patients with untreated coeliac disease. Comparison with normal subject response (Fig 1) shows that there are no significant differences in the profiles (or serum peak values) of the 'jejunal', 'ileal', or 'caecal' markers except that the 3-0-methyl-D-glucose peak at 120 minutes instead of 30 minutes. ${ }^{51}$ CrEDTA appears earlier, and reaches a 


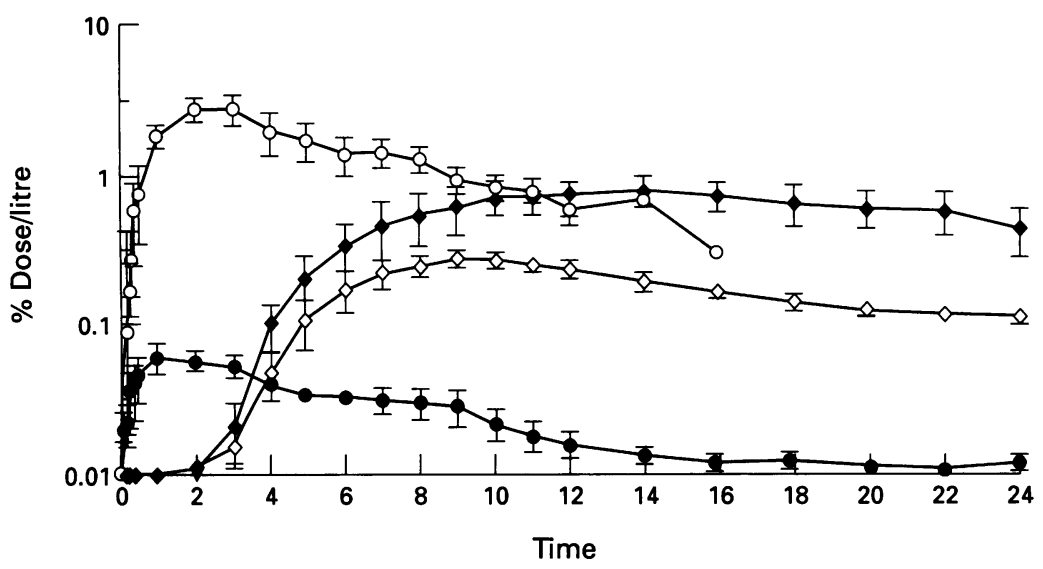

Figure 2: Permeation profiles from patients with untreated coeliac disease. Symbols as in Figure 1.

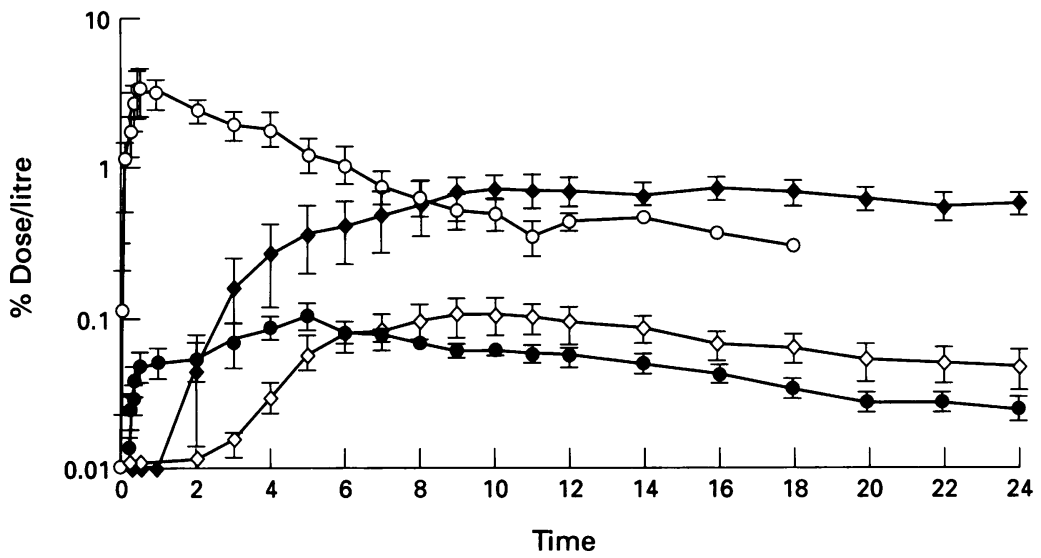

Figure 3: Permeation profiles from patients with Crohn's ileitis. Symbols as in Figure 1.

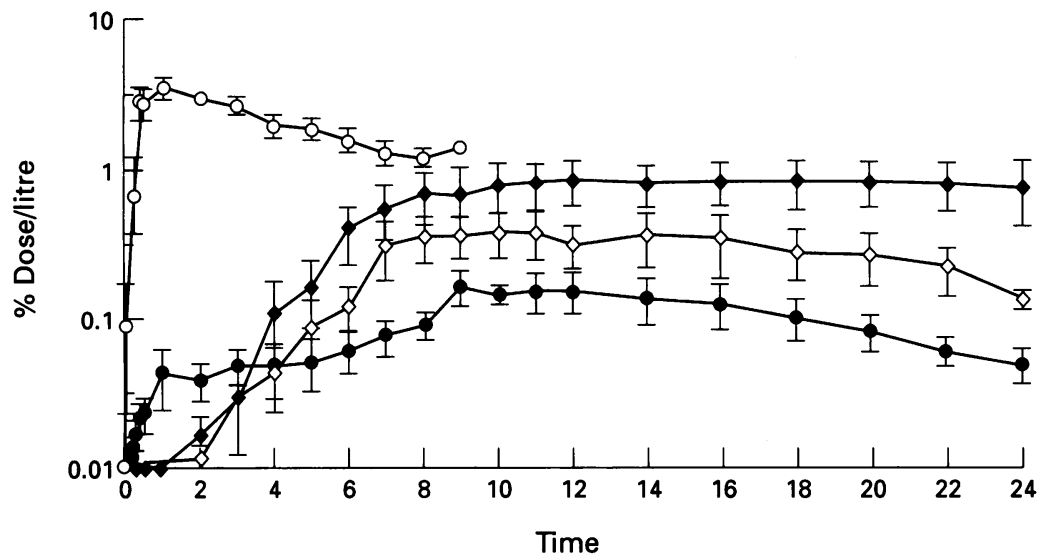

Figure 4: Permeation profiles from patients with pan-ulcerative colitis. Symbols as in Figure 1. from 0.06 to $0 \cdot 21 \%$ dose/litre and coinciding with the appearance of the 'ileal' and 'caecal' markers in the serum, was also evident in four of five patients. Unlike the normal and coeliac disease groups, significant levels of ${ }^{51} \mathrm{CrEDTA}$ were detected in serum of the Crohn's ileitis group throughout the test. The 24 hour urinary ${ }^{51}$ CrEDTA excretion, $5 \cdot 32(0.98) \%$, range 2.94 to $8.31 \%$, was significantly greater $(p<0.01)$ than in normal subjects.

Figure 4 shows the permeation profile from patients with pan-ulcerative colitis. The early peak values of ${ }^{51} \mathrm{CrEDTA}$ in serum at one hour did not differ significantly from the normal group (one patient had increased early serum values of ${ }^{51}$ CrEDTA similar to that in coeliac disease). There was, however, a clear increase in ${ }^{51}$ CrEDTA values two to five hours after the appearance of the 'ileal' and 'caecal' markers, which was evident in all the patients. The 24 hour urinary ${ }^{51} \mathrm{CrEDTA}$ excretion, $5.97(1.05) \%$, range 3.06 to $8.85 \%$, was significantly greater than in normal subjects $(\mathrm{p}<0.01)$.

Presenting the mean permeation profiles can be slightly misleading because of the variation in transit times, etc. In particular the difference between individual cases of Crohn's disease and ulcerative colitis were sharper than Figures 3 and 4 would imply. Figure 5 shows representative traces from a patient with Crohn's ileitis and ulcerative colitis where the increase in serum values of ${ }^{51} \mathrm{CrEDTA}$ clearly coincides with the appearance of the 'ileal' and 'caecal' markers in Crohn's disease and comes distinctive later in ulcerative colitis.

\section{Discussion}

This paper describes a new technique that was designed to assess the site of permeability changes within the gastrointestinal tract. The results suggest that the site of increased intestinal permeability in coeliac disease, Crohn's disease, and pan-ulcerative colitis is the diseased intestine itself. In the context of this study there are, however, a number of factors that need to be considered when interpreting the data. In particular the use of the time of appearance of indicator substances in serum and the permeation profiles is determined by a number of variables that could affect the results. These variables include the site, rate, and amount of marker permeating across the intestine, gastric emptying, intestinal dilution and transit times, metabolism in the case of sulphapyridine, distribution volume, and renal function. However, because the test substances were given at the same time the influence of some of these factors apply equally to all the test substances. Thus gastrointestinal dilution affects all the markers to a similar extent, and gastric emptying (time to appearance of 3-0methyl-D-glucose) and small intestinal transit times (time difference between 3-0-D-glucose and sulphapyridine) can be calculated and were not found to be significantly different between the patient groups. Also the mode and rate of renal excretion is similar for all the markers apart from sulphapyridine, which is ignificantly greater than in normal subjects.

Figure 3 shows the permeation profile from the patients with Crohn's ileitis. There is an early rise of ${ }^{51} \mathrm{CrEDTA}$ (in two cases indistinguishable from that seen in the patients with coeliac disease), but a second increase ranging 

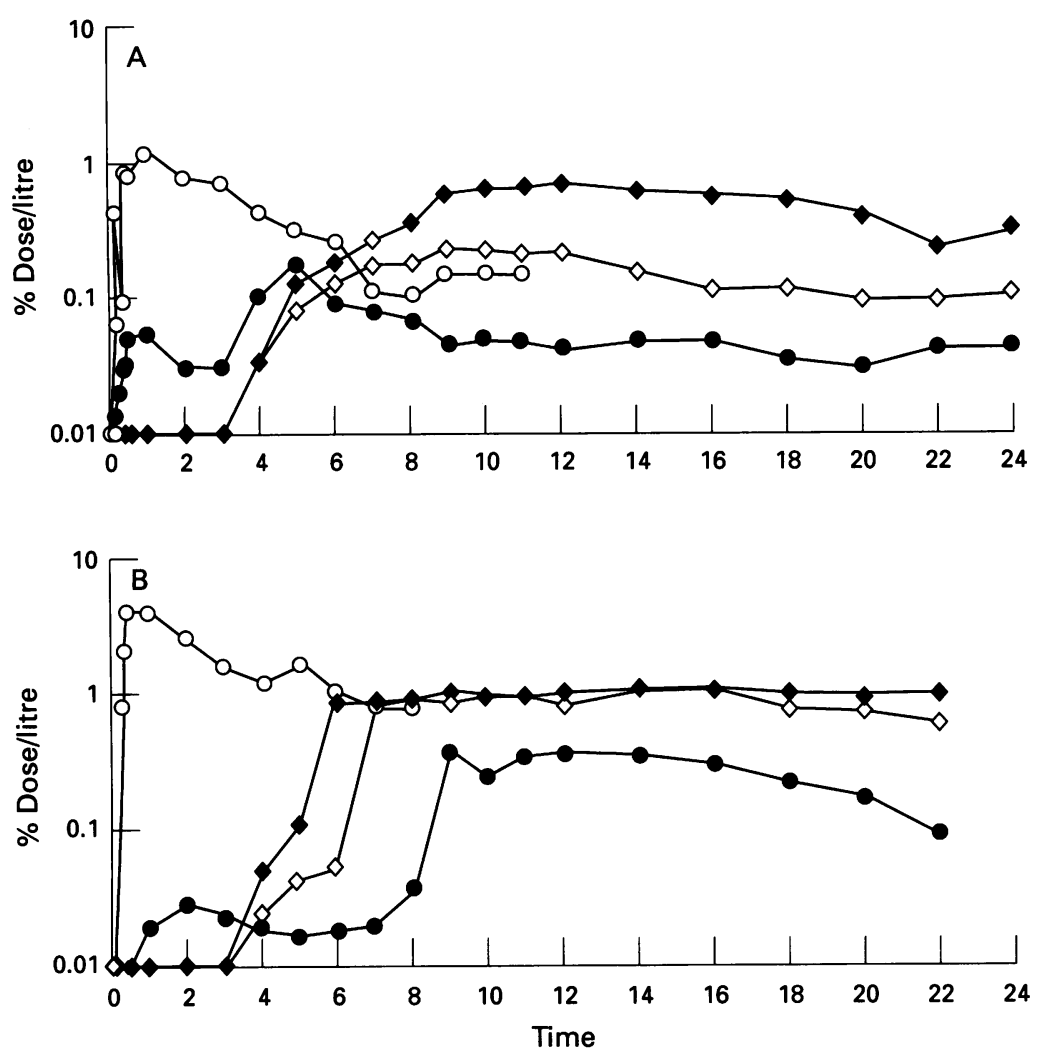

Figure 5: Comparison of profiles from an individual patient with Crohn's ileitis $(A)$ and ulcerative colitis $(B)$. The increase in serum values of ${ }^{51} \mathrm{CrEDTA}$ coincides with and follows the appearance of 'ileal' and 'caecal' markers in Crohn's disease and ulcerative colitis, respectively. Symbols as in Figure 1. detection limits of the gamma counting. Reliable detection of ${ }^{51}$ CrEDTA in serum might therefore be delayed until the bulk of the test solution had entered the jejunum.

In patients with untreated coeliac disease the appearance of ${ }^{51} \mathrm{CrEDTA}$ in serum coincided with and peaked at the same time as 3-0methyl-D-glucose suggesting that there was increased intestinal permeability in the upper small intestine. These findings are consistent with results of studies in coeliac disease, which indicate increased in vitro permeation of various markers ${ }^{18} 19$ and with freeze fracture studies, ${ }^{20}$ which demonstrate decreased strand number and depth in the intercellular junctions. The results in Crohn's disease were not as clear cut. A similar pattern of increased permeation of ${ }^{51} \mathrm{CrEDTA}$ coinciding with that of 3-0-methyl-D-glucose was found in two patients. One of these and the remaining three patients had peak values of ${ }^{51} \mathrm{CrEDTA}$ coinciding with the appearance of the 'ileal' and 'caecal' markers. As this rise (seen in Fig 5 ) in the serum values of ${ }^{51}$ CrEDTA occurred much earlier than in the patients with ulcerative colitis it seems likely that it represents increased ileal permeability to ${ }^{51}$ CrEDTA. Increased 'jejunal' permeability in some patients with Crohn's ileitis is consistent with in vitro findings of increased permeability in apparently unaffected jejunal mucosa of patients with Crohn's disease. ${ }^{19}$ The initial serum profiles of ${ }^{51} \mathrm{CrEDTA}$ in pan-ulcerative colitis were indistinguishable from normal subjects in four of five cases. The increase in serum ${ }^{51} \mathrm{CrEDTA}$ in the four patients occurred somewhat later than in the patients with Crohn's ileitis, occurring after the appearance of the 'ileal' and 'caecal' indicators. This suggests that the inflamed colonic mucosa is the site of increased permeation of ${ }^{51} \mathrm{CrEDTA}$ in ulcerative colitis as suggested by Jenkins et al. ${ }^{5}$ This is also in keeping with studies showing increased permeation of ${ }^{51} \mathrm{CrEDTA}$ after rectal administration in ulcerative colitis. ${ }^{21} 22$ Indeed, the permeation of ${ }^{51} \mathrm{CrEDTA}$ correlated significantly with histopathological assessment of disease activity in these patients. ${ }^{21}$

In summary a new non-invasive technique has been assessed that permits the localisation of the site of altered permeability with the gastrointestinal tract. The principle of the method seems to be generally applicable to other test substances than permeability probes, but there is a need to identify an equally site specific 'ileal indicator' to that of vitamin $B_{12}$, which does not have the delayed rate of absorption.

1 Menzies IS. Transmucosal passages of inert molecules in health and disease. In: Skadhauge E, Heintze $K$, eds. Intestinal absorption and secretion. Falk Symposium 36. Lancaster: MTP Press, 1984: 527-43.

2 Bjarnason I, Macpherson A, Hollander D. Intestinal permeability: an overview. Gastroenterology 1995; 108 1566-81.

3 Bjarnason I, Maxton D, Reynolds AP, Catt S, Peters TJ, Menzies IS. A comparison of 4 markers of intestinal permeability in control subjects and patients with coeliac disease. Scand 7 Gastroenterol 1993; 26: 630-9.

4 Maxton DG, Bjarnason I, Reynolds AP, Catt SD, Peters TJ Menzies IS. Lactulose, 51CrEDTA, L-rhamnose and Menzies IS. Lactulose, 51 CrEDTA, L-rhamnose and polyethylene glycol 400 as probe markers for 'in vivo' 1986; 71: 71-80. ingestion is normally somewhat distal to that of 3-0-methyl-D-glucose, but it might also be that the uptake of ${ }^{51} \mathrm{CrEDTA}$ on reaching the duodenum in the 'head' of the test solution gives serum values that are initially below the 
5 Jenkins AP, Nukajam WS, Menzies IS, Creamer B. Simultaneous administration of lactulose and $51 \mathrm{Cr}$-ethyenediaminetetraacetic acid. A test to distinguish colonic from small-intestinal permeability change. Scand $f$ Gastroenterol 1992; 27: 769-73.

6 Qvist H, Somasundaram S, Macpherson A, Menzies IS, Giercksky K, Bjarnason I. The effect of pelvic irradiation on small and large intestinal absorption and permeability in man. Gastroenterology 1994; 106: A430.

7 Fordtran JS, Clodi PH, Soergel KH, Ingelfinger JF. Sugar absorption tests, with special reference to 3-0-methyl-Dabsorption tests, with special reference to 3-0-methyl-D-

8 Kapadia CR, Serfilippi C, Voloshin KDR. Intrinsic-factor mediated absorption of cobalamine by pig ileal cells. $\mathcal{f}$ Clin Invest 1983; 71 : 440-7.

9 Kellow JE, Borody TJ, Phillips SF, Haddad AC, Brown ML. Sulphapyridine appearance in plasma after salicylazosulfapyridine. Gastroenterology 1986; 91: 396-400.

10 Best WR, Becktel JM, Singleton JW, Kern F. Development of a Crohn's disease activity index. Gastroenterology 1975; 70: 439-44

11 Truelove SC, Witts LJ. Cortisone in ulcerative colitis. Final report on a therapeutic trial. BMF 1955; 2: 1041-8.

12 Doscherholmen A, Hagen PS. Delay of absorption of radiolabelled cyanocobalamine in the intestinal wall in the preslabelled cyanocobalamine in the intestinal wall in the pres-

13 Chandler C, Garnett ES, Parsons V, Veall N. Glomerular rate measurement in man by the single injection method using 51CrEDTA. Clin Sci 1969; 37: 169-80.

14 Menzies IS, Mount JN, Wheeler MJ. Quantitative estimation of clinically important monosaccharides in plasma by rapid thin layer chromatography. Ann Clin Biochem 1978; 15: $65-76$.

15 Chungi VS, Gurvinder SR, Shargel L. A simple and rapid liquid chromatographic method for the determination of major metabolites of sulphasalazine in biologic fluids. $f$ Pharm Sci 1989; 78: 235-8.

16 Peters TJ, Hofbrand AV. Absorption of vitamin B12 by the guinea pig. I subcellular localisation of vitamin $B 12$ in ileal guinea pig. I subcellular localisation of vitamin B12 in ileal 369-82.

17 Jenkins WJ, Empsow R, Jewel DP, Taylor KB. The subcellular localisation of vitamin B12 during absorption in guinea pig ileum. Gut 1982; 22: 617-23.

18 Bjarnason I, Peters TJ. In vitro determination of intestinal permeability: demonstration of a persisting defect in patients with coeliac disease. Gut 1984; 25: 145-50.

19 Dawson DJ, Lobley RW, Burrows PC, Notman JA, Mahon M, Holmes R. Changes in jejunal permeability and passive permeation of sugars in intestinal biopsies in coeliac disease and Crohn's disease. Clin Sci 1988; 74: 427-31.

20 Madara JU. Trier JS. Structural abnormalities of jejunal epithelial cell membranes in coeliac sprue. Lab Invest 1980; 43: 254-61.

21 Rask-Madsen J, Schwartz M. Absorption of 51CrEDTA in ulcerative colitis following rectal instillation. Scand $\mathfrak{f}$ Gastroenterol 1979; 5: 361-8.

22 O'Morain C, Abelon AC, Chervli LR, Fleischner GM, Das KM.51CrEDTA a useful test in the assessment of inflammatory bowel disease. $\mathcal{f}$ Lab Clin Med 1986; 108: $430-5$. 